\title{
Maize-Soybean Intercropping System: Effects on Striga Control, Grain Yields and Economic Productivity at Tarka, Benue State, Nigeria
}

\author{
M. O. ljoyah \\ Department of Crop Production, University of Agriculture, P.M.B. 2373, Makurdi, Nigeria \\ Tel: +2348052368419 \\ E-mail address: mikejoy2005@yahoo.com
}

\begin{abstract}
On-Farm trials were conducted from July to November during the 2009 and 2010 cropping seasons, at Tarka, Benue State, Nigeria to evaluate the effects of intercropping maize and soybean on striga control, grain yields and economic productivity. The treatments consisted of sole maize, sole soybean and the intercrop of maize and soybean, replicated three times in a randomized complete block design. The results obtained showed that intercropping maize and soybean significantly $(\mathrm{P} \leq$ 0.05) reduced striga shoot count by $55.9 \%$ and $56.1 \%$ respectively, in 2009 and 2010 compared to that produced on pure maize plots. Number of affected maize plants, lodging score of maize and infestation rate were lower for intercropping than for sole maize plots. The severity level was also recorded lower for intercropping compared to that recorded for pure maize stands, where severity level is in the range of high to very high. Though, soybean yield was reduced by intercropping, however, soybean and maize intercropping system increased maize grain yield, total intercrop yield, land equivalent coefficient greater than 0.25 , land equivalent ratio values greater than one (LER $>1$ ), higher total intercrop values and monetary equivalent ratio greater than 1.00 , indicating yield and economic advantages. The implication of study showed that intercropping maize and soybean can be adopted by farmers as an efficient cropping system strategy to reduce striga infestation, increase maize yield and give greater economic productivity.
\end{abstract}

Keywords: striga hermonthica; intercropping; maize; soybean; crop values; Nigeria

\section{INTRODUCTION}

Striga hermonthica (Del.) Benth, commonly known as purple witch-weed is a parasitic plant belonging to the family Scrophulariales (Abbasher et al., 1998). The origin of striga hermonthica is unclear. It may have originated in north-east Asia (Scholes and Press, 2008). It is the largest and most destructive of the striga species and considered as one of the most serious weeds in Africa (Oswald, 2005).

In the late 1990s, 21 million hectares of cereals in Africa were estimated to be infested by $S$. hermonthica, leading to an estimated annual grain loss of 41 million tons (Gressel et al., 2004). Incidence and severity of $S$. hermonthica are exceptionally high on sorghum, pearl millet and maize, the main staple foods for over 300 million people in sub-saharan Africa (Scholes and Press, 2008). Striga infestation is extending in Africa because of the high pressure on land due to population crowding (Berner et al., 1995). However, the impact of 
striga damages depends on ecological conditions, cropping systems, local cultural practices and farmers' skills on the ecology (IITA, 2002)

In Tarka, a location in the southern guinea savanna agro-ecological zone of Nigeria, striga was rated as the farmers most serious weed problem as it leads to total crop failure (IITA, 2002). Methods commonly used in the locality in controlling striga include handpulling, root digging, early planting and crop seed dressing with salt before planting (IITA, 2002). Unfortunately, these cultural practices do not lead to any significant reduction in the density of $S$. hermonthica in affected fields (IITA, 2002). Parker (1991) observed that intercropping sorghum with cowpea invariably reduced striga infestation. Lagoke et al., (1994) also explained that intercropping is one of the striga control practices that require only adjustments in the farming systems without any additional inputs.

Though few farmers in the locality have made attempts at intercropping maize and soybean, however, there is paucity of information on its efficacy in reducing striga infestation, as well as increasing yield and economic productivity. The aim of this study, was therefore to evaluate the effects of intercropping maize and soybean on striga control, grain yields and economic productivity with the objective of determining the efficacy of the intercropping system.

\section{MATERIALS AND METHODS}

\section{1. Location of study and farmer selection}

On-farm experiments were conducted in farmer's field at Tarka district, Benue State, Nigeria, from July to November, during the planting seasons of 2009 and 2010 to evaluate the effects of intercropping maize and soybean on striga control, grain yields and economic productivity.

The farmer was selected based on availability of striga-infested plot for intercropping, willingness to grow the crop combinations, availability of labour to carry out treatment operations in time and as required, as well as allowing access of experimental farm to other interested farmers.

\section{2. Experimental area, design, treatments, variety of crops and planting}

The field $\left(75.0 \mathrm{~m}^{2}\right)$ was ploughed, harrowed, ridged and divided into twelve treatment plots, each measuring $4.5 \mathrm{~m}^{2}$. Each plot consisted of 3 ridges, spaced $1 \mathrm{~m}$ apart. The cropping systems employed include sole maize, sole soybean and the intercrop of maize and soybean on striga infested plots. The three treatments were arranged in a randomized complete block design (RCBD) with three replications. The variety of maize used was 'Suwan-1-SR' (an open pollinated striga tolerant variety), while that of soybean was 'TGX 1448-2E' (medium maturing variety, identified as a potential trap crop).

The trials were established on striga infested plots. Five maize stands per ridge were sown at a spacing of $1 \mathrm{~m} \times 30 \mathrm{~cm}$, giving a total plant population of 15 maize plants per plot (33,333 maize plants per hectare equivalent). Soybean was spaced at an intra-row spacing of 5 $\mathrm{cm}$ to give a plant population of 90 plants per plot (200,000 plants per hectare equivalent). In soles and intercrop, maize and soybean were sown at the depth of 2-3 cm. 


\section{3. Cultural practices}

Mixed fertilizer NPK (15-15-15) was applied to sole maize at the rate of $200 \mathrm{~kg} \mathrm{ha}^{-1}$, while $100 \mathrm{~kg} \mathrm{ha}^{-1}$ of single superphosphate was applied to sole soybean and for soybeanmaize mixture, $100 \mathrm{~kg} \mathrm{~N} \mathrm{ha}^{-1}, 100 \mathrm{~kg} \mathrm{P} \mathrm{ha}^{-1}$ and $100 \mathrm{~kg} \mathrm{~K} \mathrm{ha}^{-1}$ was applied (Enwezor et al., 1989). One hoe weeding was undertaken 3 weeks after planting (WAP), followed by handpulling of other weeds which was carried out at 7 WAP. Soybean was harvested when the pods have turned brown (Dugje et al., 2009). Maize was harvested at 12 WAP, when the leaves turned yellowish and fallen off which were signs of leaf senescence and cob maturity (Ijoyah and Jimba, 2012).

\section{4. Data Collection}

Data collected include striga shoot count, number of affected maize plants, lodging score of maize using a scale of 1-5, where 1 indicate all maize plants erect and 5 indicating all maize plants lodged (Berner et al., 1995), infestation rate of maize calculated as the ratio of plants affected to total number of plants sown (Carson, 1988), severity level of infestation using a scale of $0-4$ where 0 indicate no infestation and 4 indicating a very high severity level (Carson, 1988), and grain yields of maize and soybean. Other data calculated include total intercrop yield, striga weed yield, land equivalent ratio (LER) as described by Willey (1985), land equivalent coefficient (LEC) as described by Adetiloye et al., (1983), maize and soybean crop values as soles and in intercrop, total intercrop values of the component crops and monetary equivalent ratio (MER) as described by Adetiloye (1988).

\section{5. Statistical analysis}

The data were statistically treated using the Analysis of variance (ANOVA) for randomized complete block design and the Least Significant Difference (LSD) was used for mean separation $(\mathrm{P} \leq 0.05)$ following the procedure of Steel and Torrie (1980).

\section{RESULTS AND DISCUSSION}

\section{1. Effect of intercropping on striga control}

Intercropping maize and soybean significantly $(\mathrm{P} \leq 0.05)$ reduced striga shoot count at 12 WAP. Intercropping significantly $(\mathrm{P} \leq 0.05)$ reduced striga shoot count by $55.9 \%$ and $56.1 \%$ respectively, in 2009 and 2010, compared to that produced from sole maize plots (Table 1). This result confirmed that of Dembele and Kayentao (2002) who reported that intercropping sorghum-cowpea reduced by $83 \%$ emerged striga. Mashark et al., (2006) also reported that the maize varieties grown in Ghana under intercropping supported fewer striga plants compared to those grown in sole cropping.

The lower number of affected maize plants produced under intercropping with soybean (Table 1) could be due to the smothering effect of the soybean plants, which might have created a microclimate that could have affected the emergence and growth of striga plants. The created micro-climate could also have been conducive to the growth of micro-organism such as Fusaria, a bio-control agent against striga. Carson (1988) also reported that the spreading vegetation of non-host crops (trap crops) smothers emerging striga plants. Intercropping maize and soybean significantly $(\mathrm{P} \leq 0.05)$ reduced number of affected maize plants by $43.3 \%$ and $50.5 \%$ respectively, in 2009 and 2010 compared to that obtained from pure maize plots. 
Table 1. Effect of intercropping maize and soybean on striga control in a striga infested plot at Tarka, Nigeria during the 2009 and 2010 cropping seasons.

\begin{tabular}{|c|c|c|c|c|c|c|c|c|c|c|}
\hline \multirow{2}{*}{$\begin{array}{l}\text { Cropping } \\
\text { systems }\end{array}$} & \multicolumn{2}{|c|}{$\begin{array}{l}\text { Striga shoot count } \\
\text { at } 12 \text { WAP }\end{array}$} & \multicolumn{2}{|c|}{$\begin{array}{c}\text { Number of affected } \\
\text { maize plants at } \\
\text { 12WAP }\end{array}$} & \multicolumn{2}{|c|}{$\begin{array}{l}\text { Maize lodging } \\
\text { score }\end{array}$} & \multicolumn{2}{|c|}{$\begin{array}{c}\text { Infestation rate } \\
(\%)\end{array}$} & \multicolumn{2}{|c|}{$\begin{array}{l}\text { Severity } \\
\text { level }\end{array}$} \\
\hline & 2009 & 2010 & 2009 & 2010 & 2009 & 2010 & 2009 & 2010 & 2009 & 2010 \\
\hline Sole maize & 35.2 & 30.1 & 12.7 & 10.5 & 4.8 & 5.0 & 84.7 & 70.0 & 4.0 & 3.0 \\
\hline Maize-soybean & 15.5 & 13.2 & 7.2 & 5.2 & 2.8 & 2.2 & 48.0 & 34.7 & 2.2 & 2.2 \\
\hline Means & 25.4 & 21.7 & 10.0 & 7.9 & 3.8 & 3.6 & 66.4 & 52.4 & 3.1 & 2.6 \\
\hline $\begin{array}{c}\text { LSD } \\
(\mathrm{P}<0.05)\end{array}$ & 6.8 & 9.2 & 3.1 & 2.4 & 1.0 & 1.2 & 15.2 & 18.5 & 1.2 & 0.5 \\
\hline $\mathrm{Cv}(\%)$ & 10.5 & 12.3 & 6.2 & 8.4 & 12.8 & 16.2 & 12.8 & 16.2 & 16.2 & 16.2 \\
\hline
\end{tabular}

Lodging score: using a scale of $1-5$, where $1=$ all maize plants erect and $5=$ all maize plants lodged. Infestation rate: ratio of plants affected to total number of plants sown. Severity level: using a scale of 1-4 where: 0- no infestation; 1- Low severity level (less than $25 \%$ of maize plants affected); 2-Medium severity level (26-50 \% of maize plants affected); 3-High severity level (51-75\% of maize plants affected); 4-Very high severity level (above $75 \%$ of maize plants affected).

WAP: weeks after planting.

The lodging score recorded from pure maize stands was higher compared to that obtained from intercropping (Table 1). The greater number of striga shoot count produced from pure maize plot and the greater number of affected maize plants could have been responsible. Intercropping maize and soybean significantly $(\mathrm{P} \leq 0.05)$ reduced infestation rate compared to that recorded for pure maize plot (Table 1).

The severity level of striga was lower under intercropping than in pure maize stands, where the severity level was in the range of high to very high (Table 1).

\section{2. Effect of intercropping on grain yields and Striga weed yield}

In both years, soybean planted as pure stands recorded greater yield than that produced from intercropped soybean (Table 2). This could be attributed to the shading effect of maize over soybean, and the variety of soybean used as a trap crop.

Intercropping maize with soybean increased maize grain yield by $50.0 \%$ and $51.7 \%$ respectively, in 2009 and 2010 compared to that produced from pure maize stands. Dembele and Kayentao (2002) reported that sorghum grain yield had been improved from $37.0 \%$ to $80.0 \%$ in the intercropped plots of sorghum and cowpea.

Intercropping maize and soybean also increased total intercrop yield. The total intercrop yields produced in both years were greater than the component crop yields and sole crop yields (Table 2).

The striga weed yield was higher in sole maize plots than in sole soybean plots. The reduction in weed yield in soybean plots could be due to the smothering effect of soybean on striga emergence. Intercropping maize and soybean reduced striga weed yield by $57.1 \%$ and $75.0 \%$ respectively, in 2009 and 2010, compared to that obtained from sole maize plots, and 
by $50.0 \%$ and $60.0 \%$ respectively, in 2009 and 2010, compared to that produced from sole soybean plots (Table 2). Land equivalent ratio values were greater than one (LER $>1$ ), indicating that it was advantageous having the component crops in mixture. Land equivalent coefficient (LEC) values were also greater than 0.25 , signifying yield advantage of the intercropping system (Table 2).

Table 2. Yields of maize and soybean, total intercrop yield, striga weed yield, land equivalent ratio (LER) and land equivalent coefficient (LEC) as influenced by intercropping maize and soybean on striga infested plot at Tarka, Nigeria during 2009 and 2010 cropping seasons.

\begin{tabular}{|c|c|c|c|c|c|c|c|c|c|c|c|c|}
\hline \multirow[t]{2}{*}{$\begin{array}{l}\text { Cropping } \\
\text { systems }\end{array}$} & \multicolumn{2}{|c|}{$\begin{array}{c}\text { Maize grain } \\
\text { yield } \\
\left(\mathrm{t} \mathrm{ha}^{-1}\right)\end{array}$} & \multicolumn{2}{|c|}{$\begin{array}{c}\text { Soybean } \\
\text { yield } \\
\left(\mathrm{t} \mathrm{ha}^{-1}\right)\end{array}$} & \multicolumn{2}{|c|}{$\begin{array}{c}\text { Total } \\
\text { intercrop } \\
\text { yield }\left(\mathrm{t} \mathrm{ha}^{-1}\right)\end{array}$} & \multicolumn{2}{|c|}{$\begin{array}{c}\text { Striga weed } \\
\text { yield } \\
\left(\mathrm{t} \mathrm{ha}^{-1}\right)\end{array}$} & \multicolumn{2}{|c|}{ LER } & \multicolumn{2}{|c|}{ LEC } \\
\hline & 2009 & 2010 & 2009 & 2010 & 2009 & 2010 & 2009 & 2010 & 2009 & 2010 & 2009 & 2010 \\
\hline Sole maize & 1.3 & 1.4 & - & - & - & - & 0.7 & 0.8 & - & - & - & - \\
\hline $\begin{array}{c}\text { Sole } \\
\text { soybean }\end{array}$ & - & - & 1.5 & 1.6 & - & - & 0.6 & 0.5 & - & - & - & - \\
\hline $\begin{array}{l}\text { Maize- } \\
\text { soybean }\end{array}$ & 2.6 & 2.9 & 1.4 & 1.5 & 4.0 & 4.4 & 0.3 & 0.2 & 2.93 & 3.01 & 1.86 & 1.95 \\
\hline
\end{tabular}

$$
\text { LER }=\frac{\text { Intercrop yield of crop A }}{\text { Sole crop yield of crop A }}+\frac{\text { Intercrop yield of crop B }}{\text { Sole crop yield of crop B }}
$$

\section{LEC: $\mathrm{La} \times \mathrm{Lb}($ LER of main and intercrop)}

The total intercrop values recorded in both years, were greater than the component crop values and sole crop values, while the monetary equivalent ratio (MER) values were greater than 1.00, thus signifying economic advantage of the intercropping system, as a strategy for the control of striga (Table 3).

Table 3. Crop values of maize and soybean (US $\$ \mathrm{ha}^{-1}$ ), total intercrop value and monetary equivalent ratio (MER) as influenced by intercropping maize and soybean on striga infested plot at Tarka,

Nigeria during 2009 and 2010 cropping seasons.

\begin{tabular}{|c|c|c|c|c|c|c|c|c|}
\hline \multirow[t]{2}{*}{$\begin{array}{c}\text { Cropping } \\
\text { systems }\end{array}$} & \multicolumn{2}{|c|}{$\begin{array}{l}\text { Maize value } \\
\text { US } \$\left(t^{-1} a^{-1}\right)\end{array}$} & \multicolumn{2}{|c|}{$\begin{array}{l}\text { Soybean value } \\
\text { US } \$\left(\mathbf{t h a}^{-1}\right)\end{array}$} & \multicolumn{2}{|c|}{$\begin{array}{c}\text { Total intercrop } \\
\text { value US\$ }\left(\mathrm{t} \mathrm{ha}^{-1}\right)\end{array}$} & \multicolumn{2}{|c|}{ MER } \\
\hline & 2009 & 2010 & 2009 & 2010 & 2009 & 2010 & 2009 & 2010 \\
\hline Sole maize & 18,833 & 11,666 & - & - & - & - & - & - \\
\hline Sole soybean & - & - & 28,717 & 32,820 & - & - & - & - \\
\hline Maize-soybean & 22,666 & 24,166 & 28,717 & 30,769 & 51,383 & 54,935 & 1.79 & 1.67 \\
\hline
\end{tabular}

Crop values of maize at $\$ 130 \mathrm{~kg}^{-1}$ and that of soybean at $\$ 320 \mathrm{~kg}^{-1}$ (Exchange rate 1US $\$$ to $\$ 156.00$ in year 2010)

N: denotes Nigeria currency (Naira)

$\operatorname{MER}=\left(\mathrm{r}_{1}+\mathrm{r}_{2}\right) / \mathrm{R}$ 
Where $r_{1}$ and $r_{2}$ : Monetary returns of component crops in mixture $\mathrm{R}$ : higher sole crop monetary return compared to the other.

Focus group discussion (FGD) and pair-wise ranking were used in obtaining farmers evaluation on the effectiveness of maize-soybean intercropping in the control of striga (Table 4). Farmers expressed preference for soybean (TGX 1448-2E) used in intercrop with maize (SUWAN-1-SR) as a cropping system strategy in the control of striga hermonthica, as it promotes higher maize yield, greater soil improvement and requires less labour. However, they indicated more access to the maize and soybean varieties for distribution to other interested farmers wishing to adopt the technology.

Table 4. Farmers evaluation on the effectiveness of maize-soybean intercropping.

\begin{tabular}{|c|c|c|c|c|c|c|}
\hline \multirow{2}{*}{$\begin{array}{c}\text { Cropping } \\
\text { systems }\end{array}$} & $\begin{array}{c}\text { Effectiveness } \\
\text { on striga } \\
\text { control }\end{array}$ & $\begin{array}{c}\text { Yields } \\
\text { obtained }\end{array}$ & $\begin{array}{c}\text { Soil } \\
\text { improvement }\end{array}$ & $\begin{array}{c}\text { Seed } \\
\text { availability }\end{array}$ & Labour & Priority \\
\cline { 2 - 7 } & $*$ & $*$ & $*$ & $* *$ & $* *$ & $*$ \\
\hline $\begin{array}{c}\text { Sole maize } \\
\text { Soybean }-\end{array}$ & $* *$ & $* *$ & $* *$ & $*$ & $*$ & $* *$ \\
\hline
\end{tabular}

* bad/less

$* *$ better/more

\section{CONCLUSION}

From the results obtained, it can be concluded that it is effective intercropping maize and soybean in the control of striga, as well as improving maize grain yield and economic productivity. This is associated with a significant reduction of striga shoot count, reduced number of affected maize plants, higher maize grain yield, higher total intercrop yield, higher total intercrop value, land equivalent ratio values greater than one (LER $>1$ ), land equivalent coefficient values greater than 0.25 and monetary equivalent ratio (MER) value greater than 1.00 .

It is however, recommended that further investigation be evaluated across a wider combination of maize and soybean varieties and across different locations within the southern guinea savannah agro-ecological zone of Nigeria.

\section{References}

[1] Abbasher A.A., Hess D.E., Sauerborn J., African Crop Science Journal 6 (1998) 179-188.

[2] Adetiloye P.O. (1988). A review of current competition indices and models for formulating component proportions in intercropping in cassava based cropping systems research II, pp. 72-90.

[3] Adetiloye P.O., Ezedinma F.O.C., Okigbo B.N., Ecology modeling 19 (1983) 27-39. 
[4] Berner D.K., Kling J.G., Singh, B.B., Plant Disease 79 (1995) 652-660.

[5] Carson A.G., Tropical Pest Management 34 (1988) 349-358.

[6] Dembele B., Kayentao M. (2002). Integrated striga management technologies: From research to farmers. Proceedings of the $4^{\text {th }}$ general workshop of the Pan African Control Network (PASCON), 28 Oct. - 1 Nov., 1996, Mali.

[7] Dugje I.Y., Omoigui L.O., Ekeleme F., Bandyopadhyay R., Kumar P.L., Kamara A.Y. (2009). Farmers guide to soybean production in Northern Nigeria, pp. 16.

[8] Enwezor W.O.E., Udo J., Ajotade K.A. (1989). Fertilizer procurement and distribution. Fertilizer use and management practice for crops in Nigeria. Savenda Publishers, Nsukka, Nigeria. Pp. 25-28.

[9] Gressel J., Hanafi A., Head G., Marasas W., Obilana A.B., Ochanda J., Souissi T., Tzotzos G., Crop Protection, 23(2004) 661-689.

[10] Ijoyah M.O., Jimba J., Journal of Biodiversity and Environmental Science 2(2) (2012) 38-44.

[11] International Institute of Tropical Agriculture (2002). Community workshop on striga and imperata management: Tarka local Government, Benue State, Nigeria, 18-21 March, 2002.

[12] Lagoke S.T.O., Shebayon J.A.Y., Weber G., Olufajo O.O., Elemo K.A., Adu J.K., Emechebe A.M., Singh B.B., Adeoti A.A. (1994). Survey of striga problem and evaluation of striga control methods and packages in crops in the Nigerian savanna. In: Improving striga management in Africa. Proceedings, $2^{\text {nd }}$ General Workshop of PASCON, 23-29 June, 1991, Nairobi, Kenya.

[13] Mashark S.A., Denwar N.N., Haruna M., Journal of Agronomy 5(4) (2006) 617-620.

[14] Oswald A., Crop Protection 24(4) (2005) 333-342.

[15] Parker C., Crop Protection 10 (1991) 6-22.

[16] Scholes D.J., Press C.M., Plant Biology 11(2) (2008) 180-186.

[17] Steel R.G.D., Torrie J.H. (1980). Principles and procedures of statistics. A Biometrical Approach. $2^{\text {nd }}$ edition, McGraw Hill, New York, pp. 633.

[18] Willey R.W. (1985). Expl. Agric. 21 (1985) 119-133. 